\title{
Tetratropis terrina sp. nov., a new calcareous dinoflagellate cyst from the Upper Campanian polyplocum zone of Lägerdorf (NW Germany)
}

\author{
KATARZYNA-MARIA BISON ${ }^{1}$, JENS WENDLER ${ }^{1}$, GERARD J.M. VERSTEEGH ${ }^{2,3}$ \& HELMUT WILLEMS $^{1}$ \\ ${ }^{1}$ Division of Palaeontology, University of Bremen, FB 5, Geowissenschaften, Postfach 330440, D-28334 Bremen, Germany \\ (e-mail: kbison@uni-bremen.de). \\ ${ }^{2}$ Netherlands Institute for Sea Research, PO Box 1790 AB Den Burg, Texel, Netherlands. \\ ${ }^{3}$ University of Utrecht, Faculty of Earth Sciences, Budapestlaan 4, 3594 Utrecht, Netherlands.
}

\begin{abstract}
A new calcareous dinoflagellate cyst species, Tetratropis terrina sp. nov., with an apparent stratigraphically narrow range is described from the Upper Campanian Bostrychoceras polyplocum zone of the Lägerdorf chalk sequence (NW Germany). The electron microscopic and light microscopic analyses show that $T$. terrina has both a pithonelloid wall type with uniformly inclined wall crystallites and a reduced peridiniacean paratabulation pattern. The prominent morphological similarities of $T$. terrina to the other two Tetratropis species (T. patina and T. corbula) justify the affiliation of the new species to the genus. As a result of the extension of the morphological spectrum by the new species, the genus Tetratropis Willems, 1990 has been emended. J. Micropalaeontol. 23(2): 127-132, November 2004.
\end{abstract}

\section{INTRODUCTION}

The chalk sections of Lägerdorf-Hemmoor-Kronsmoor (NW Germany) cover a nearly complete Upper Cretaceous succession from the Middle Coniacian Volviceramus koneni zone to the Upper Maastrichtian Belemnella occidentalis zone (Ernst, 1984; Schulz et al., 1984). Earlier investigations on calcareous dinoflagellate cysts from the lower part of the chalk sections by Willems $(1985,1988,1990,1994)$ and Hildebrand-Habel \& Willems (1997) showed diverse calcareous dinoflagellate assemblages. These are dominated by the common Upper Cretaceous Pithonelloideae Pithonella sphaerica (Kaufmann, 1865) and P. ovalis (Kaufmann, 1865). The dinoflagellate assemblages also contain rare species of the genus Tetratropis at certain short stratigraphic intervals. A complete evaluation of the so-called 'calcispheres' of the entire Upper Cretaceous standard section of NW Germany is in preparation. This study extends the systematic inventory of calcareous dinoflagellate cysts by the description of a new species $T$. terrina sp. nov. which was found in the interval 2.0-2.2 $\mathrm{m}$ above the flint bed F101b (Fig. 1) located in the Upper Campanian Bostrychoceras polyplocum zone (Schulz et al., 1984) of the Lägerdorf section (Heidestrasse). So far specimens of the genus Tetratropis have been found exclusively in the chalk pits of Lägerdorf. All species of the genus Tetratropis are characterized by a short stratigraphical range.

\section{MATERIAL AND METHODS}

The studied composite section of the Lägerdorf and Kronsmoor pits in NW Germany (Fig. 1) was sampled at a mean sample spacing of $5 \mathrm{~m}$ and analysed for calcareous dinoflagellate cysts. The material was processed by repeated freezing and thawing in saturated sodium sulphate solution. Size fractions were separated by wet sieving using mesh sizes of $20 \mu \mathrm{m}$ and $125 \mu \mathrm{m}$. To clean the cysts the size fraction $20-125 \mu \mathrm{m}$ was treated with ultrasound. Cyst specimens were picked with an eyelash from the dried residue using a binocular microscope at a magnification of $\times 120$ and mounted on a stub for electron microscopic (SEM) studies. Some specimens were broken after first observation in order to examine the wall structure. To analyse the crystallographic orientation of the wall crystallites, thin sections were applied following the procedure of Janofske (1996). However, for specimens with large crystallites, such as the species investigated, thin section preparation bears the risk of destruction and crystallite reorientation, resulting in cuts useless for a crystal-optical analysis (Wendler \& Willems, 2004). Therefore, polarization-optical investigations were carried out using untreated specimens embedded in immersion oil and thin sections.

Unprocessed sample material (sample 1; F101b +2.0-2.2 m), washed residue, SEM stubs and the polarization-optical slides analysed are stored at the Division of Historical Geology and Palaeontology, Bremen University.

\section{TAXONOMY}

The taxonomy follows the classification of Fensome et al. (1993) which subdivides the Calciodinelloideae according to their wall type and type of archaeopyle. Four wall types of calcareous dinoflagellate cysts are defined by the crystallographic orientation of the wall crystals (Young et al., 1997). These wall types are: (1) radial (orthogonal), with strictly radial orientation of c-axes; (2) pithonelloid, with uniformly inclined $c$-axes; (3) oblique, with irregularly obliquely orientated $c$-axes; and (4) with tangentially orientated $c$-axes.

\section{SYSTEMATIC DESCRIPTION}

Division Dinoflagellata (Bütschli, 1885)

Subdivision Dinokaryota Fensome et al., 1993 Class Dinophyceae Pascher, 1914

Subclass Peridiniphycidae Fensome et al., 1993 Order Peridiniales Haeckel, 1894 Suborder Peridiniineae Autonym Family Peridiniaceae Ehrenberg, 1831 Subfamily Calciodinelloideae Fensome et al., 1993

Diagnosis. Fensome et al. (1993, p. 133). Peridiniaceae in which the episomal tabulation is bipesioid and the Kofoid second anterior intercalary plate is hexa (i.e. six-sided). The cyst wall includes a calcareous layer or layers. The archaeopyle is centred about the apical region. 


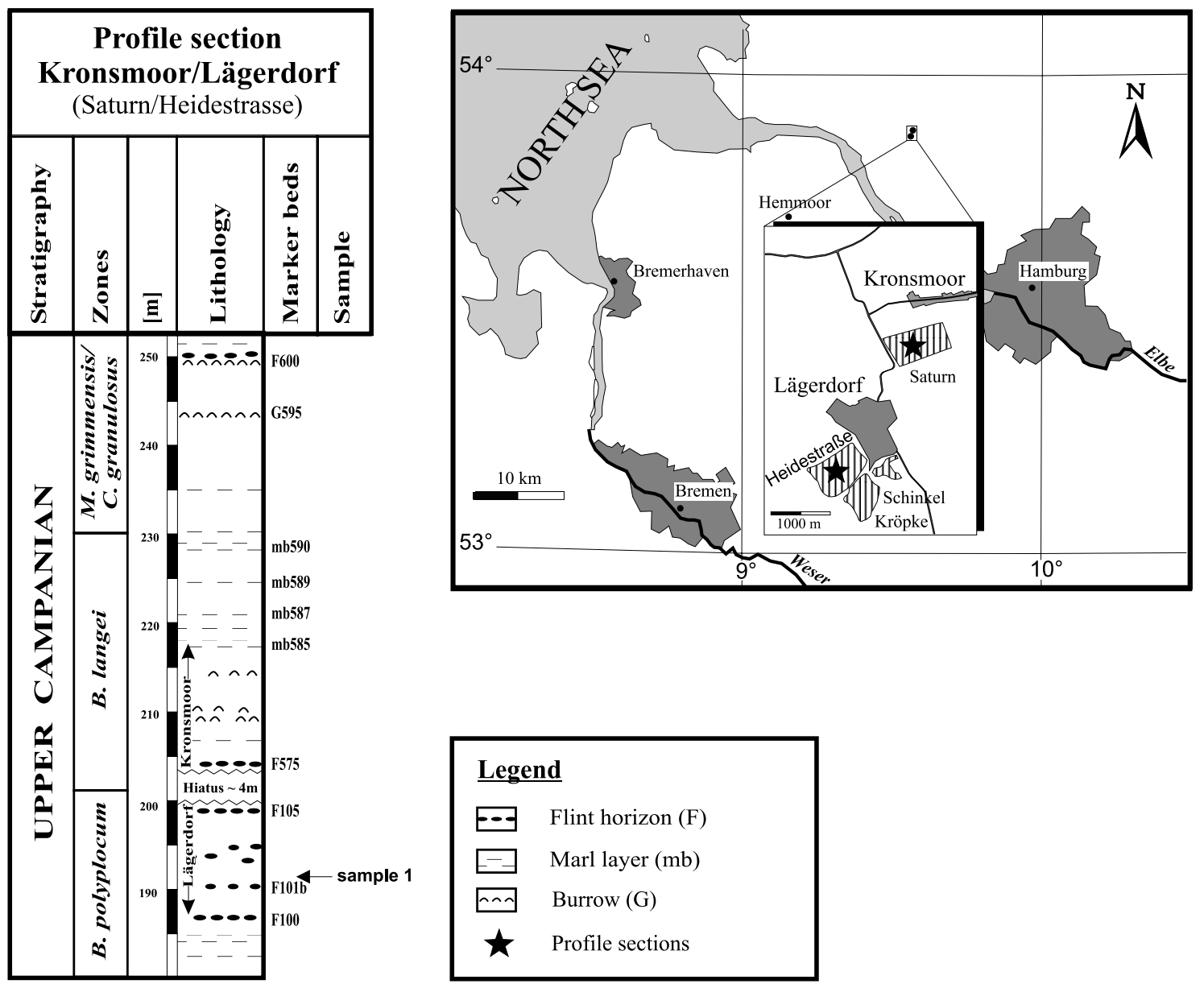

Fig. 1. Geographical location of the chalk pits of Lägerdorf (Heidestrasse, Schinkel, Kröpke) and Kronsmoor (Saturn) and simplified stratigraphic profile of a part of the combined Lägerdorf/Kronsmoor section investigated (map modified after Hildebrand-Habel \& Willems, 1997). Sample 1 $(\mathrm{F} 101 \mathrm{~b}+2.0-2.2 \mathrm{~m})$ originates from the chalk pit Heidestrasse near Lägerdorf. The metre scale of the combined section indicates the distance from the marl layer M1 (Lower Campanian, Sphenoceramus lingua/Gonioteuthis quadrata zone) (Ernst, 1984; Schulz et al., 1984).

Genus Tetratropis Willems, 1990

Type of genus. The holotype of Tetratropis corbula Willems, 1990.

Included species. Tetratropis corbula Willems, 1990 and Tetratropis patina Willems, 1990.

Original diagnosis. Willems (1990, p. 242, in German), translated. Single-walled calcareous dinoflagellate cysts with a slightly flattened apical-antapical shape. The cyst surface is characterized by four concentric, equator-parallel ridges that divide the cyst body into several segments. The arrangement of the ridges resembles a reduced peridinialean paratabulation which, however, is mostly obscured within the cyst segments. The equatorial ridge divides the cyst into trapezoidal-shaped epi- and hypocysts. The round archaeopyle is centred in apical position at the epicyst. Columnar wall-crystallites are orientated evenly inclined to radially to the cyst surface and produce apically-antapically arranged rows at the surface.

Remarks. The new species, T. terrina, fits well within the genus Tetratropis, except for the number of ridges. Rather than describing a new, monotypical genus it is much more straight forward to emend the genus Tetratropis such that it also includes T. terrina.

Emended diagnosis. Pithonelloid, apically-antapically flattened calcareous dinoflagellate cysts. The cyst surface is characterized by concentric equator-parallel ridges dividing the cyst body into several test segments. A distinctive equatorial ridge, thought to reflect the paracingulum, subdivides the cyst into two trapezoidal halves (epi- and hypocyst). The circular archaeopyle is located in the central part of the epicyst (apical segment).

Tetratropis terrina sp. nov.

(Pl. 1, figs 1-6; Pl. 2, figs 1-6)

Derivation of name. Terrine (French)='earthen dish': due to the tureen-like shape.

Diagnosis. An apically-antapically flattened (length/width ratio c. 0.5) species of Tetratropis with a reduced paratabulation consisting of two equator-parallel ridges. Epi- and hypocyst are separated by a distinct circular ridge (paracingulum). The hypocyst encompasses approximately two-thirds of the cyst and is trapezoidally shaped in side view. In antapical position a second circular ridge is developed. The single-layered cyst wall 

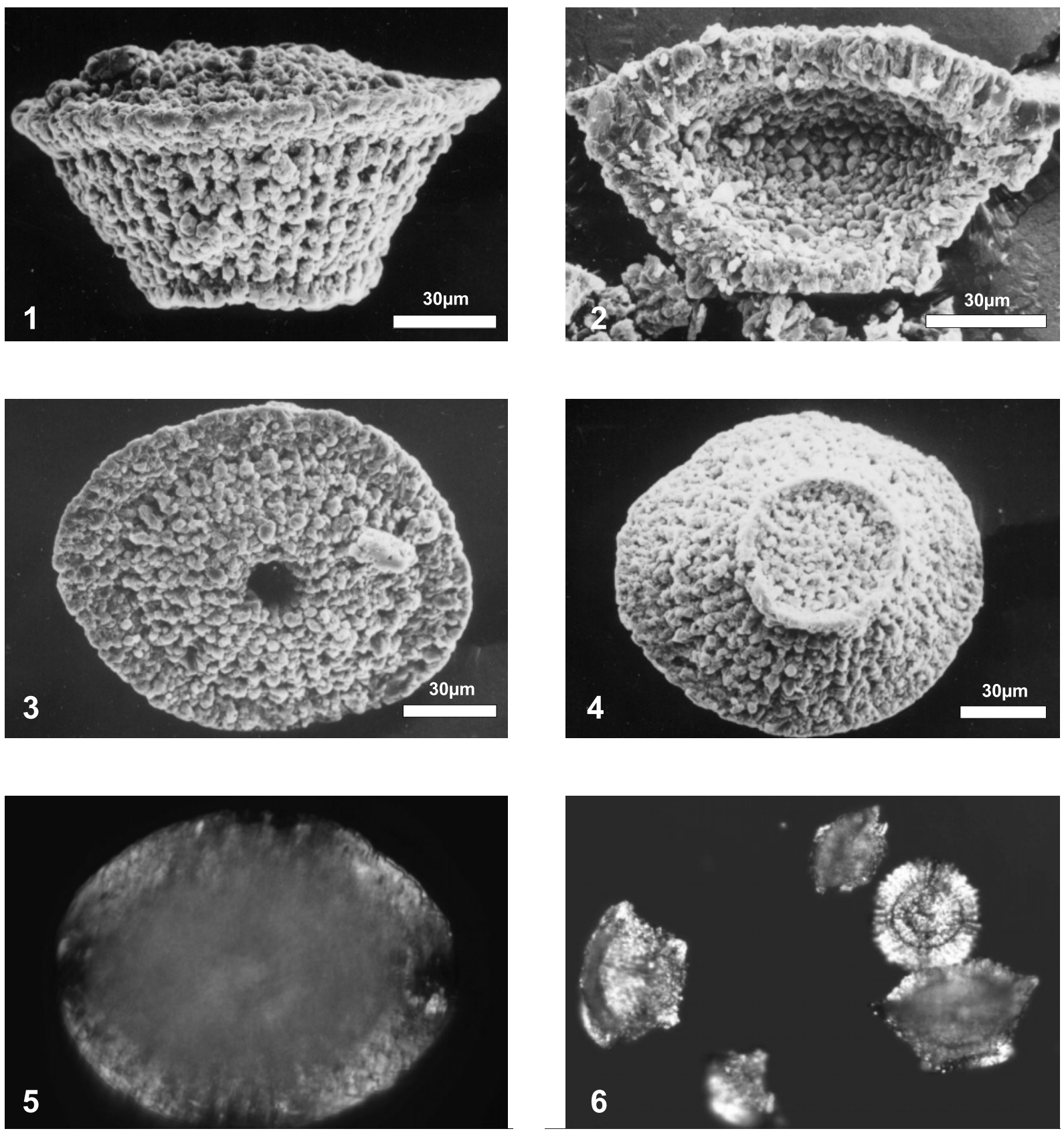

Explanation of Plate 1. Tetratropis terrina sp. nov. fig. 1. Side view (holotype, cyst 20.4/4). Note the reticular cyst surface pattern of distinctive longitudinal and less pronounced latitudinal rows. fig. 2. Longitudinal cross-section (paratype, cyst 20.4/11). Broken specimen showing the varying thickness of the wall that consists of evenly inclined to radially orientated crystallites. fig. 3. Apical view (holotype, cyst 20.4/4). The cingular ridge is oval. Note the small archaeopyle, $20 \mu \mathrm{m}$ in diameter. fig. 4. Antapical view (paratype, cyst 20.4/14). The antapical ridge occasionally shows a slight subangular shape and encircles a concave antapical segment. fig. 5. Apical view under crossed nicols. A prominent extinction cross is visible in the cingular ridge. fig. 6. Different views under crossed nicols. A prominent extinction cross is visible in apical and side views of whole and broken specimens.

consists of uniformly inclined to radially orientated crystallites. The crystals on the cyst surface resemble a reticular pattern of longitudinal and latitudinal rows. A small circular archaeopyle is present in apical position.

Holotype. Cyst 20.4/4 (Pl. 1, figs 1, 3).

Paratypes. Seven cysts from the type-stratum (F101b +2.0 2.2 m; sample 1): Cyst 20.4/11 (Pl. 1, fig. 2), cyst 20.4/14 (Pl. 1, fig. 4), cyst 20.1/7 (Pl. 2, fig. 1), cyst 20.3/24 (Pl. 2, figs 2, 3), cyst
20.1/3 (Pl. 2, fig. 4), cyst 20.4/12 (Pl. 2, fig. 5), cyst 20.4/10 (Pl. 2 , fig. 6).

Type locality. Lägerdorf (Heidestrasse) pit SSW of Lägerdorf (NW Germany).

Type stratum. White chalk from the interval $2.0-2.2 \mathrm{~m}$ above the flint-horizon F101b, B. polyplocum zone, Upper Campanian (sample 1, Fig. 1). 

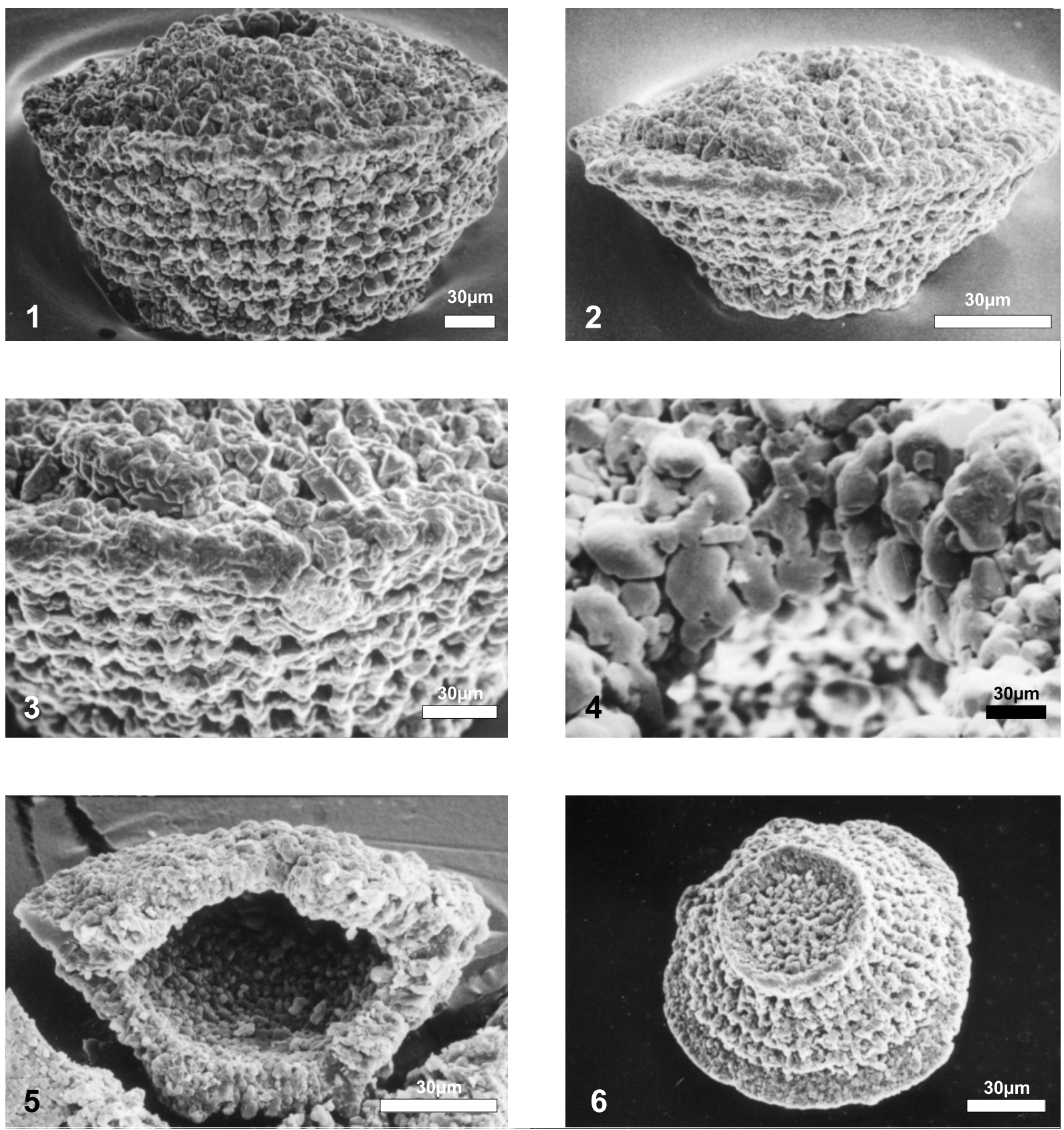

Explanation of Plate 2.. Tetratropis terrina sp. nov. fig. 1. Side view (paratype, cyst 20.1/7). Morphotype with a relatively large diameter of the antapical ridge (approximately $59 \%$ of the diameter of the paracingulum). Angle of inclination of the 'side thighs' is about $60^{\circ}$. fig. 2. Side view (paratype, cyst 20.3/24). Apical-antapically flattened cyst. The hypocyst is clearly trapezoidal-shaped, with a relatively small diameter of the antapical ridge (approximately $50 \mu \mathrm{m}$ ) which is about $38 \%$ of the paracingulum ridge. The angle of inclination of the 'side thighs' is about $50^{\circ}$. fig. 3. Detail of the paracingulum (paratype, cyst 20.3/24). The crystals of the paracingulum are coalesced into an irregularly formed unit. Note the reticular pattern of the cyst surface below the paracingulum. fig. 4. Detail of the archaepyle (paratype, cyst 20.1/3). Note the aggregate-like shape of the crystallites typical of the Pithonelloideae. fig. 5. Longitudinal cross-section (paratype, cyst 20.4/12). Specimen with a relatively thick antapical segment. fig. 6. Antapical view (paratype, cyst 20.4/10). Note the subangular shape of the paracingulum.

Other material examined. Thirty-one additional cysts from the type stratum. Twenty-two cysts were studied under the SEM, thin sections were prepared of three cysts and light optical investigations on whole or mechanically broken cysts were carried out on six cysts.
Repository. All type material and other material examined herein is held in the Geosciences Collection of the University of Bremen, Germany. Collection numbers: GSUB M20, GSUB M21, GSUB M22, GSUB M23, GSUB M24, GSUB M25, GSUB M26, GSUB M27. 


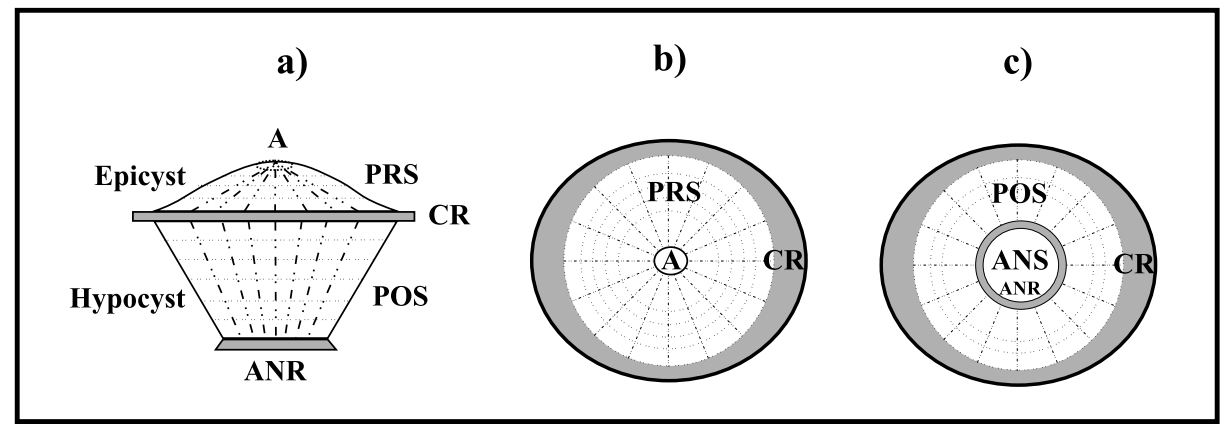

Fig. 2. Schematic sketch of the reduced paratabulation pattern of Tetratropis terrina sp. nov.: (a) side view; (b) apical view; (c) antapical view. A, archaeopyle; PRS, pre-cingular segment; CR, cingular ridge; POS, post-cingular segment; ANR, antapical ridge; ANS, antapical segment.

Description and dimensions. Apically-antapically flattened cysts. The cysts show morphometric variations: The cyst height generally varies from $68-76 \mu \mathrm{m}$, with a minimum of $41 \mu \mathrm{m}$. Maximum transversal diameter ranges $116-144 \mu \mathrm{m}$. The cysts have a height/width ratio of $0.4-0.6$.

Paratabulation. Two prominent equator-parallel ridges encircle the cyst body (Fig. 2; Pl. 1, fig. 1; Pl. 2, figs 1, 2, 6). The larger of these ridges is oval (Pl. 1, figs 3, 5) and is positioned above the cyst equator. It can be interpreted as the paracingulum. The cingular ridge is $15-21 \mu \mathrm{m}$ high and divides the cyst into a smaller epicyst (about one-third of the cyst) and a larger hypocyst. The epicyst resembles a convex lid (Pl. 2, figs 1, 2). In a central apical position the small round archaeopyle with a diameter of $11-19 \mu \mathrm{m}$ is visible (Pl. 1, fig. 3). The hypocyst encompasses approximately two-thirds of the cyst and is trapezoidally shaped in side view. The smaller, about $6 \mu \mathrm{m}$ high ridge in antapical position encompasses a round to sub-angular, flat antapical segment. The area of the hypocyst between the two ridges is interpreted as the post-cingular segment. Morphological elements which could be interpreted as the parasulcus are missing, thus the cysts cannot be orientated into a ventral- and dorsal-side.

Walls. The wall is single layered (Pl. 1, fig. 2; Pl. 2, fig. 5). Its thickness ranges from $21 \mu \mathrm{m}$ at the cingular ridge to a minimum of $4.5 \mu \mathrm{m}$ at the antapical segment. The crystals on the cyst surface resemble a reticular pattern of longitudinal and latitudinal rows. The wall crystallites are arranged radially to uniformly, inclined relative to the cyst surface (pithonelloid wall type). They are apically inclined (Pl. 1, fig. 2; Pl. 2, fig. 5). In particular, the ridges on the cyst surface which are formed by distally extended wall crystallites clearly show an extinction cross under polarized light indicative of the pithonelloid wall type (P1. 1, figs 5, 6). The crystallites are $1.9-3.4 \mu \mathrm{m}$ thick columnar aggregates with irregular surfaces and rounded to rhombohedral crystal ends (Pl. 2, fig. 4).

Comparison. Tetratropis terrina sp. nov. is similar to the other two species of the genus Tetratropis in terms of the principal paratabulation pattern formed by circular and equator-parallel ridges and by the wall characteristics which are marked by a uniformly inclined orientation as well as a typical habitus and growth pattern of the crystals. T. terrina differs from them in its reduced number of ridges and the cyst morphology. T. patina and $T$. corbula have four circular ridges and equally sized epiand hypocysts. T. patina is much smaller and only $36-48 \mu \mathrm{m}$ in apical-antapical direction and the diameter at the paracingulum ridge is $65-81 \mu \mathrm{m}$ (Willems, 1990). The smallest of the three species, T. corbula, is less flattened compared to the two other species. Its paratabulation pattern additionally reflects a parasulcus.

Compared to other species of the Pithonelloideae, the wall characteristics of $T$. terrina are comparable to those of the genus Pithonella (Kaufmann, 1865) (Keupp \& Kienel, 1994), although Pithonella is characterized by a double-layered wall, whereas Tetratropis has only a single layer. Apart from the pithonelloid wall structure, T. terrina is similar to species of Pithonella, in particular to $P$. cardiiformis Zügel, 1994 and $P$. discoidea Willems, 1992 in terms of size and shape of the archaeopyle and the outside shape and size of the cyst test. However, the apical inclination of the wall crystallites which is typical for Tetratropis species differs from Pithonella; in this aspect Tetratropis more closely resembles Bonetocardiella conoidea Bonet, 1956. Both Pithonella and Bonetocardiella species differ from T. terrina since clearly visible paratabulation features are absent.

Stratigraphic range and abundance. Within the sample investigated, Pithonella sphaerica clearly dominates $(>80 \%)$ the calcareous dinoflagellate assemblage. The second most frequent $(6 \%)$ calcareous dinoflagellate is $T$. terrina. $P$. cardiiformis and Lentodinella danica Kienel, 1994 which also belong to the Pithonelloideae, are less abundant $(<4 \%)$. Like the other species of Tetratropis, T. terrina seems to have a restricted stratigraphical range in the Upper Cretaceous of the Boreal Realm. The narrow range of $T$. terrina makes it a potentially important stratigraphic marker. However, up to now, specimens of the genus Tetratropis have only been found in the chalk pits of Lägerdorf. Since there are no other studies on calcareous dinoflagellates of the $B$. polyplocum zone, the assessment of the stratigraphic applicability, as well as the environmental characteristics of $T$. terrina, require further studies.

Frequency and distribution in the examined samples. $T$. terrina was so far only found in a sample from the B. polyplocum zone, $2 \mathrm{~m}$ above the flint horizon F101b $(+2.0-2.2 \mathrm{~m})$. They make up about $6 \%$ of the calcareous dinoflagellate cyst association.

Remarks. On the basis of polarization optical thin section analysis of the original material and the type species $T$. patina 
Willems, 1990 and T. corbula Willems, 1990, Hildebrand-Habel \& Willems (1997) suggested that Tetratropis had an obliquipithonelloid wall instead of pithonelloid as was originally suggested by Willems (1990). This combination was rejected by Wendler \& Willems (2004) on the basis of new light optical studies. The investigations on T. terrina sp. nov. presented here also confirm the pithonelloid nature of the genus. A disorientation of the crystals during thin section preparation is most likely responsible for the misinterpretation of the orientation of the crystallographic $c$-axis by Hildebrand-Habel \& Willems (1997).

\section{ACKNOWLEDGEMENTS}

The sample material was kindly made available through the courtesy of Dr J. Schönfeld (Kiel). Tania Hildebrand-Habel and Michael Streng are acknowledged for their support during the investigation of the discussed sections. For the technical support at the SEM, the authors thank Hartmut Mai. Karin Zonneveld gave valuable comments. Nicole Zatloukal and Angelika Fresemann assisted with the photographic work. The authors also thank the anonymous referee and Paul Dodsworth for helpful reviews and the Journal Editor, John Gregory, for useful suggestions.

\section{Manuscript received 2 October 2003 Manuscript accepted 24 February 2004}

\section{REFERENCES}

Ernst, H. 1984. Bericht über eine Grossprobenserie im SchreibkreideRichtprofil von Lägerdorf/Kronsmoor (M-Coniac bis U-Maastricht). Mitteilungen Geologisch-Paläontologisches Institut Universität Hamburg, 57: 137-145.
Fensome, R.A., Taylor, F.J.R., Norris, G., Sarjeant, W.A.S., Wharton, D.I. \& Williams, G.L. 1993. A classification of living and fossil dinoflagellates. American Museum of Natural History, Micropalaeontology, Special Publication, 7: 351pp.

Hildebrand-Habel, T. \& Willems, H. 1997. Calcareous dinoflagellate cysts from the Middle Coniacian to Upper Santonian chalk facies of Lägerdorf (N Germany). Courier Forschungsinstitut Senckenberg, 201: 177-199.

Janofske, D. 1996. Ultrastructure types in Recent 'calcispheres'. Bulletin de l'Institute Oceanographique, Monaco, 14(4): 295-427.

Keupp, H. \& Kienel, U. 1994. Wandstrukturen bei Pithonelloideae (Kalkige Dinoflagellaten-Zysten): Biomineralization und systematische Konsequenzen. Abhandlungen der Geologischen BundensanstaltA., Festschrift zum sechzigsten Geburtstag von Erik Flügel, 50: 197-217.

Schulz, M.-G., Ernst, H. \& Weitschat, W. 1984. Stratigraphie und Fauna der Ober-Kreide (Coniac - Maastricht) von Lägerdorf und Kroonsmoor (Holstein). Exkursionsführer Erdgeschichte des Nordseeund Ostseeraumes. Geologisch-Paläontologisches Institut Universität Hamburg, 483-517.

Wendler, J. \& Willems, H. 2004. Pithonelloid wall-crystallite orientation of the Upper Cretaceous calcareous dinoflagellate cyst genus Tetratropis. Review of Palaeobotany and Palynology, 129: 133-140.

Willems, H. 1985. Tetramerosphaera lacrimula, eine intern gefächerte Calcisphaere aus der Ober-Kreide. Senckenbergiana lethaea, 66(3/5): 177-201.

Willems, H. 1988. Kalkige Dinoflagellaten-Zysten aus der oberkretazischen Schreibkreide Fazies N-Deutschlands (Coniac bis Maastricht). Senckenbergiana lethaea, 68(5/6): 433-477.

Willems, H. 1990. Tetratropis, eine neue Kalkdinoflagellaten-Gattung (Pithonelloideae) aus der Oberkreide von Lägerdorf (N-Deutschland). Senckenbergiana lethaea, 70: 239-257.

Willems, H. 1994. New calcareous dinoflagellates from the Upper Cretaceous white chalk of northern Germany. Review of Palaeobotany and Palynology, 84: 57-72.

Young, J.R., Bergen, J.A., Bown, P.R., Burnett, J.A., Fiorentino, A., Jordan, R.W., Kleijne, A., van Niel, B.E., Romein, A.J.T. \& von Salis, K. 1997. Guidelines for coccolith and calcareous nannofossil terminology. Palaeontology, 40: 875-912. 